\title{
Supporting Literacy and Positive Identity Negotiations with Multimodal Comic Composing
}

\author{
LINDSEY MOSES \\ Arizona State University \\ STEPHANIE F. REID \\ University of Montana
}

\begin{abstract}
This study explores how an alternative writing unit with a focus on comics, choice, and publishing supported positive identity development in a fourth-grade classroom. Many traditional literacy practices with an emphasis on skills marginalize students from underrepresented populations. This study reports literacy practices that countered the production of previously established unequal relationships and instead supported bilingual students' negotiation of positive identities. We conducted an analysis of two bilingual case studies to examine the ways in which the shift from traditional literacy skills/practices to multimodal formats provided opportunities for students who were traditionally marginalized to renegotiate identities as experts and authors.
\end{abstract}

Keywords: Identity, Multimodality, Comics, Writing, Multimodal Composing

\section{Introduction \\ "We could never do this type of writing in my school." \\ "We don't have time for students to do writing workshop or choose their own topics." "It sounds great, but my principal would never let me teach this way."}

These are quotes Lindsey hears each year when she teaches a graduate class on teaching writing workshop (with an emphasis on student voice, choice, and audience) in the elementary grades. Many teachers are faced with curricular mandates and pressure for raising test scores, particularly in schools that serve children who are experiencing poverty. These schools often receive prescriptive curriculum that leaves little room for student choice and instead provides "direct instruction of measurable academic skills" (Dyson, 2018, p. 241). As many schools move to suggesting or requiring teachers adhere to these prescriptive and formulaic instructional programs with "fidelity", teachers often feel they do not have opportunities to provide student-centered instruction because of the heavy emphasis on skill development.

We believe that many traditional literacy instructional practices with an emphasis on skill steps marginalize students from under-represented populations. The idea of students who are successful in skills-focused educational contexts are representative of cultural and ideological judgements which can complicate educational experiences for children of color and students experiencing poverty (Delpit, 2012). As Dyson (2018) stated, "The staircase of skill steps becomes an oddly tenuous structure in dynamic, interactive 
space. Moreover, written language proves to have a role both in producing unequal relations and in countering that production" (p. 237). Restrictive skills-based writing instruction often creates a community dynamic that privileges traditional, school-based literacy practices.

The purpose of this study is to explore what literacy practices in a student-centered unit of study countered the production of previously established unequal relationships and instead supported students' negotiation of positive identities as authors and experts in a fourth-grade classroom. Two bilingual students who scored significantly different on grade-level literacy assessments (proficient and three years below grade level) were selected as case studies to provide an in-depth analysis of the writing experiences and identity negotiations. Both students, Andre and Sabrina (all names are pseudonyms), experienced marginalization because their first and home language, Spanish, was not allowed in their school setting because they attended public school in a state that had strict English Only language policies and laws which privileged English and discriminated against Spanish and other languages. Classism, racism, and linguistic discrimination and many other forms of oppression have historically been problematic in the United States, and, while we did not observe any oppression issues in the classroom, these have undoubtedly influenced the educational experiences and resources of two MexicanAmerican, bilingual students attending a school with high levels of poverty. Additionally, Andre had a disability and received special education service which resulted in removing him from the classroom community to focus on basic literacy skills. Andre reported not liking reading or writing, and Sabrina reported enjoying both.

In this study, we sought to examine if the shift from traditional literacy skills/practices to multimodal formats would provide opportunities for traditionally marginalized students during literacy instruction to renegotiate identities as experts. This identity development and renegotiation of positive identity development can provide social and academic opportunities for students who find literacy challenging (Guccione, 2011; Moses \& Kelly, 2017) because learners' identities contribute to what they perceive they can or cannot do (Hall, 2009).

The following research question guided the study: How do the literacy practices and tools made available in a writing unit of study with a focus on comics, choice, and publishing allow fourth-grade students to position themselves as experts?

In the following introduction, we provide a situational overview of the development of this study and educational context.

\section{Situational Overview: Student-Driven Collaborative Research}

On the last night of Lindsey's writing course, Sam, a student and fourth-grade teacher, approached her and said, "I have a lot of kids who really hate and struggle with writing. I would love to have them have some more authentic experiences with writing. Could you come in to my class and help me after the state assessments are over?" (Personal Communication, 2016). Sam and Lindsey decided to conduct a formative study in which they would collaborate on planning, instruction, and assessment.

Sam and Lindsey met to talk about the unit of study that would take place after the state assessments were completed (he had academic freedom for his writing instruction after that point). One of the aspects they decided to focus on was audience and publishinghe identified that students' writing was always written with him as the audience and that 
did not serve an authentic purpose. They also wanted student interest to drive the unit of study. Lindsey began observing in the classroom during the language arts period (they were following the district curriculum for reading and writing at this point). She noticed one student, Andre, who did not sit with the other students on the carpet during instruction. He sat at his desk in a swivel chair, often looking at a comic book, and did not participate in the lessons. When Lindsey inquired about Andre, Sam reported that he read at about a firstgrade level and was pulled from literacy instruction for special education services, so he did not participate in the typical grade level language arts lessons. They agreed that they would identify a unit of study and opportunities for composing/writing that would be inclusive of all students and would have Andre stay in the classroom during the writing block.

As Lindsey continued observing in the classroom and conversing with students, their interest in comics and graphic novels became clear. Initially, Sam and Lindsey were reluctant to select this as a unit of study because of their lack of knowledge and experiences with comics. However, the students were most interested in comics, so they decided on a unit of study centered on the comics medium. First, they flooded the classroom library with 150 comics and graphic novels. Then, building on research and pedagogy literature on teaching comics, they designed a general outline for the unit that would result in the publishing of student work and a culminating comic release night where the studentauthor/illustrators would sign their publications for family and friends.

\section{Theoretical Framework}

We situate our work in two distinct but interconnected theoretical frameworks: Sociocultural theories of learning and social semiotic multimodality.

\section{Sociocultural Theories of Learning}

We bring a sociocultural perspective and believe all learning is a social process in which people use mediational/cultural tools to participate in mediated action (Vygotsky, 1978; Wertsch, 1998). Dyson (2018) notes, "Literacy studies with a sociocultural and participatory view of learning must confront the issue of institutional belonging. Without a sense of inclusion, there are no relationships within which literacy learning can unfold" (p. 236). Our study attempts to examine identity development among two case studies during their negotiations for institutional belonging during a comics unit of study. One student, Andre, initially had many moments of situated "encounters" with others (Massey, 2005, p.20) that positioned him as not belonging. The other student, Sabrina, positioned herself and was positioned by others as an academic expert and central to the literacy classroom community. To better explore how both students managed to develop positive identities as experts and authors, we draw on theoretical frames from the sociocultural tradition: communities of practice (Lave \& Wenger, 1991; Wenger, 1998), cultural tools (Wertsch, 1998), and identity (Moje, Luke, Davies, \& Street, 2009).

\section{Communities of Practice: Participatory Trajectories and Negotiations}

We draw on communities of practice (Lave \& Wenger, 1991; Wenger, 1998) in order to examine our case studies' situated learning and participatory trajectories and negotiations in the classroom community of practice. Participation in communities of practice can take on multiple forms and evolve overtime. Lave and Wenger (1991) explain 
that all communities develop accepted practices or cultural tools that allow for participation and learning while also signaling membership to that community. Mastery of knowledge and cultural tools of a community allows newcomers to move from peripheral participation to full participation in the community of practice. The use of accepted practices and membership negotiation signals participants' identities and evolving forms of membership. In a writing classroom community of practice, learning is not merely situated in a specific practice, activity, or event, but it also involves students' social, cultural, and historical contexts. In order to renegotiate and/or maintain their membership status, students must adapt their use of cultural tools relevant to the constantly changing practices of the context.

\section{Cultural Tools}

All communities of practice have accepted practices and/or tools that allow for participation and signal membership. The mastery and appropriation of cultural tools allow people to participate in mediated action in a community of practice (Wertsch, 1998). "Agents, cultural tools, and the irreducible tension between them always have a particular past and are always in the process of undergoing further change" (Wertsch, 1998, p. 34). Consideration of both the agent and cultural tools inform researchers about how these elements combine to produce the mediated action that is being examined (Wertsch, 1998). In this study, we are examining the action of positive identity development, so we must examine the context, agent (student), and ways in which they use tools made available within the classroom community of practice to position themselves as experts and authors. Cultural tools are used with social interaction to change the physical or social environment and are often created for purposes other than mediated action as the goal (Wertsch, 1998). In a classroom setting, this might involve literacy practices that were originally designed for academic purposes, but were eventually taken up or appropriated as tools to signal membership and identities as experts.

\section{Identity}

Gee (2001) defines identity as 'being recognized as a certain 'kind of person,' in a given context" (p. 99). He notes that when people are working to achieve a certain identity, they also need others to recognize them as taking on that identity. Moje, Luke, Davies, \& Street (2009) note that identity can be used to stereotype, marginalize, or privilege. Identity research can take on many different lenses (Moje et al., 2009). For purposes of this study, we are working within the framework of identity as position. Holland and Leander (2004) explain that positioning "involves socially producing particular individuals and groups as culturally imagined types such that others and, even the person herself, at least temporarily treat her as though she were such a person" (p. 130). We examine ways in which students are positioned and position themselves as peripheral or full members of a community who identify themselves as experts and authors.

Critical literacy scholars have emphasized the need to examine the relations of power present in educational institutions (Comber, 2013; Janks, 2010; Kamler, 2001; Luke, 2014). In addition, power negotiations and identity development greatly influence the ways in which students are able to participate in the literate classroom community (Hall, 2012; Moses, 2013). The ability to be seen and develop an identity as a competent and literate member of the classroom community greatly influences students' educational experiences, yet it is rarely a focus of educational reform. As students in Christian and Bloome's (2004) 
study articulated, "Learning to read is who you are" (p. 365). Cummins (2017) notes, "One of the major reasons why mainstream initiatives aimed at closing the achievement gap have produced such meager results is that issues related to societal power relations and identity negotiation in schools have been largely ignored" (p. 421).

There remains a need for research studying what identities are made available to students who speak home languages other than English and how those students appropriate practices of the community to gain membership (Norton \& Toohey, 2002). We attempt to identify and describe the unit of study experiences and the ways in which this created opportunities for positive identity negotiations. In this context, we define positive identity negotiations and development as instances in which students position themselves and/or are positioned by others as a competent member of the literate community, a contributor of new knowledge related to literacy, an author, or an expert. We use the term expert as a signaled identity when a student signals (or another student signals) that they have expertise about the topic. For example, this might happen when other students seek out their knowledge or advice, or when the teacher uses their work or thinking to introduce a new idea. This also happened when a student corrected the teacher's understanding or use of terminology.

\section{A Social Semiotic Approach to Multimodality}

In schools, high-stakes assessment and increasingly standardized curricula has resulted in a more regulated version of literacy that prioritizes written language and venerates certain genres of texts (Davis \& Willson, 2015; Vasudevan, Schultz, \& Bateman, 2010). In contrast, a social semiotic approach to multimodality insists on the equality of all signs in all modes (Jewitt, Bezemer, \& O'Halloran, 2016). This means that all modes of communication and representation have the potential to contribute equally to the meaning of any multimodal text or artifact (Kress, 2010). Although mode has been defined differently by scholars working within different approaches to multimodality, mode is defined here in alignment with social semiotic traditions as "a set of socially and culturally shaped resources for meaning" (Jewitt et al., 2016, p.9; Kress, 2010). Modes defined in this approach to multimodality include, for example, written language, spoken language, image, sound, and gesture.

A multimodal text or ensemble (Kress, 2010) is comprised of multiple modes. Film, webpages, and comics are all examples of multimodal texts. As a multimodal text, the comic offers readers the opportunity to make meaning from combinations of printed language, images, and design elements such as gutters or panels (see Low, 2012; Wallner, 2018). Importantly, the reader must attend to all the semiotic resources and consider the meaning potential rendered by the combinations or "orchestration" of modes (Kress, 2010). Thus, readers should consider attending to the messages made available through a given mode and examine how those interpretations are impacted and shaped by the co-existence of multiple other modes (Jewitt et al., 2016; Kress, 2010). Each mode fulfils semiotic tasks that other modes cannot undertake.

The multimodal approach matters in literacy education. Flewitt (2008) argued that children must learn to become literate in many ways due to the number of multimodal texts and interactions they encounter in their daily lives. She stated that a multimodal approach to literacy expands the possibilities for considering what counts as literacy across the multiple sites that comprise children's lives. According to Cowan and Kress (2017), the 
goal of multimodal research is a democratic goal. When all modes are accounted for in school contexts, all makers of meaning can be awarded recognition, not just those who excel at the kinds of assessment and literacy-oriented tasks frequently valued in classroom spaces (Gee \& Hayes, 2011).

\section{Literature Review}

\section{School-Based Writing and Identity}

Many researchers have explored literacy practices related to identity negotiations (i.e. Bloome et al., 2005; Dyson, 2018; Dyson, 2006). "Too often ESL speakers and writers accept the judgments of teachers as truth, unaware of the social and political realities that reinforce the labeling" (Fernsten, 2008). Unfortunately, students who speak English as an additional language and whose writing does not fit the standard, monolingual expectations are often labeled as struggling, deficient, or lacking in ability (Harris, 1997). Traditional prompt-writing instruction with a focus on grammar, mechanics, and school-based writing procedures (often referred to as the basics) have the potential to marginalize students from diverse cultural and linguistic backgrounds. Dyson (2006) argues that "the basics as ordinarily understood are alienated from, rather than situated within, familiar communicative practices, steeped, as they are, in social meaning and ideological values" (p. 10). In contrast to a focus on the basics, reading and writing workshop approaches to instruction have been documented to promote literacy for students from diverse backgrounds, particularly when the literacy practices draw upon students' interests and experiences (Au, 1993, 1998).

\section{Comics and School Reading and Writing Practices}

Comics do not usually feature as part of dominant school literacy practices because they fall outside of both the traditional literary canon and the understanding of literacy as reading and/or writing logocentric texts (Low, 2012). While literacy researchers have investigated the potential role comics might play within school contexts, such research has not always assisted with the admittance of comics into mainstream curricular spaces as complex texts worthy of literary analysis and discussion. For example, while demonstrating that fifth graders enjoy graphic novels and find comics engaging, Jennings, Rule, \& Vander Zanden (2014) seemed to negate the meaning potential of images by stating that "students who struggle with reading can readily connect to graphic novels because they can use the pictures to help them visualize the text" (p.260). From this perspective, images reiterate the words and provide assistance to students who find reading language difficult. Language remains the most important resource for meaning-making. As a result, graphic novels are often considered less academic than written language texts (Jiménez \& Meyer, 2016) which suggests that readers of graphic novels and comics may also be viewed as less scholarly. Arguments for counting these kinds of multimodal texts as "real" reading have been formulated by people within and beyond the academy (Mlynek, 2020).

Providing an alternative perspective, other research has demonstrated that studying graphic novels and comics in the elementary classroom (Brenna, 2013; Ranker, 2007) can be a valuable enterprise. Comics support the teaching and learning of many of the reading strategies taught through use of more traditional logocentric texts (Dallacqua, 2013). Furthermore, comics are constructed from design features and images that require students to utilize visual meaning-making skills and competencies (Jiménez \& Meyer, 2016; Meyer 
\& Jiménez, 2017). Multimodal text interpretation and composition requires students to demonstrate expertise in multiple modes of representation and communication and the different ways in which modes can be combined within multimodal ensembles. Importantly, incorporating multimodal practices and texts into the literacy curriculum aligns with the Universal Design for Learning (UDL) framework (Kleinfeld, 2019; Rice \& Dunn, 2020). UDL supports the design of inclusive classroom curricula and encourages teachers to remove barriers to students' learning. Permitting students to build knowledge across a variety of texts and formats and express themselves through use of multiple modes, media, and tools are two UDL principles that support the incorporation of comics into school contexts.

\section{Comics and Identity}

Comics challenge dominant school literacy practices that focus on reading and writing, print language, and traditional, hierarchical notions of literacy (Low, 2012; Maggio, 2007). When schools fail to acknowledge a range of modes as valuable resources for meaning-making, schools also fail to acknowledge those students who use and enjoy communicating with those unacknowledged modes (Bezemer \& Kress, 2016; Cowan \& Kress, 2017). All modes, and not just written and spoken language, "support individuals, groups, and institutions as they gain and sustain expertise and identity" (Heath \& Street, 2008, p.21). Expanding ideas about what counts as literacy increases opportunities for students to exercise their voice and find success in school classroom communities (Street, 1984).

Reading and composing comics extends the opportunities for students to construct identities as successful literacy practitioners. In classrooms that celebrate multimodality, students are able to apply meaning-making knowledge and use tools gleaned from communities of practice beyond school (Moje, Giroux, \& Muehling, 2017). Norton (2003) explored how comics allowed students to take ownership of their learning. Students drew upon their own background and experiences when reflecting upon, engaging with, and defending comics. Vasudevan, Schultz, and Bateman (2010) attended to how students authored new literate identities and assumed positions of authority within the classroom while composing with resources drawn from multiple modes. A movement away from narrow, language-based versions of literacy expands teachers' ability to recognize identities and expertise that might have remained invisible otherwise (Carter, 2007; Vasudevan et al., 2010).

Increasing the availability of diverse graphic texts created by \#ownvoices authors and illustrators in classrooms extends the availability of representational mirrors (Bishop, 1990) available to students from non-dominant social groups. Such increased availability makes possible opportunities to engage in talk about social constructions such as race (Low, 2017) and disability (Kersten, 2018). Furthermore, comics and graphic have the potential to disrupt silence regarding race (Low, 2017) because "in the comics medium, race is visibly marked and ever-present, even when it is textually absent and seemingly ignored (Grice, Rebellino, \& Stamper, 2017, p. 48). Comics can be deconstructed and critiqued (Low, 2017), but students can also use comics and genres typically associated with the medium to create their counter-stories (Torres \& Tayne, 2017), offer corrective representations of non-white characters (Low, 2017), and engage in restorying literacy practices (Thomas \& Stornaiuolo, 2016). 


\section{Methods}

This study is part of a larger, formative study (Reinking \& Bradley, 2008) focused on the integration of multimodal texts for reading and writing instruction. We obtained Institutional Review Board approval for the study that was then approved by school administration. The teacher signed consent forms to participate in the study. Then, parents of the students in the class were sent bilingual consent forms for student participation. All parents signed the consent forms, so we gave the students assent forms in English and Spanish to inquire about their interest in participating in the study. All students opted into participation. Part of the assent form included wording to let students know they could stop study participation without any negative consequences at any time.

This study was focused on the identity development of two case studies. We selected two case studies according to their variation of literacy assessment scores: a female (who performed on grade level on literacy assessments) and male (who performed significantly below grade level on literacy assessments) who both spoke Spanish as their first language. We investigated the research question using a microethnographic approach while collecting data three to four days a week over a six-week period. Microethnographies "usually focus on specific behavioral interactions in specific institutional settings" (Moll, Diaz, Estrada, and Lopes, 1992, p. 341). We focused on interactions related to literacy during the writing period.

Using a descriptive case study methodology (Merriam, 1998), we focused on identity negotiations related to composing and interactions during the writing period. Descriptive case studies provide opportunities to explore the complexities of a situation or context and examine the multiple factors that contribute to the complexities (Merriam, 1998).

\section{Setting and Participants}

School. We purposefully selected a Title I public classroom in the U.S. (at least $40 \%$ of the student population must be considered low income to be Title I) with a range of linguistic and economic diversity. The school is situated in an urban area in a large Southwestern city in the United States. The study took place in an English-instruction classroom. The student population consists of the following ethnicities: Hispanic-67\%, White-12\%, American Indian/Alaska Native- 6.5\%; Asian- 2\%; Black- 6\%; Two or more races- $3 \%$. Academic performance on state assessments are as follows: English- $24 \%$ proficient; Math- 26\% proficient; Science- 37\% proficient. Of school attendees, $82 \%$ of students qualify for free and reduced lunch.

Classroom. All students in the fourth-grade classroom agreed to participate in the research study, and all of their parents consented to their participation. The classroom included 27 students with 14 girls and 13 boys. The classroom background was representative of the school demographics reported previously. The language arts curriculum used in this classroom was part of the district-created curriculum and was used by all teachers in the district. However, the district curriculum was created only to be implemented until the state assessments. The teachers had academic freedom for instruction for the remaining six weeks of school. 
Sam. Sam is a white male teacher in his mid-forties. He has been teaching in the intermediate grades for six years. He received his teaching certificate and Master's in Elementary Education and Teaching at the start of his career. During this study, he was in the process of completing another Master's degree in Literacy Education.

Case study: Sabrina. Sabrina is a 10-year-old Latina student whose parents both speak Spanish at home. Her parents are also fluent in English. Sabrina performed as proficient on the state language proficiency assessment (on a scale of pre-emergent, basic, intermediate, and proficient). Her academic performance in reading, math, and science are proficient, according to the state assessments. Sabrina is an outgoing student who regularly raises her hand to contribute to conversations. Students also often went to Sabrina to ask for help on assignments.

Case study: Andre. Andre is an 11-year-old Latino student whose parents both speak Spanish at home. His mother is conversationally fluent in English, and his father speaks exclusively in Spanish. Andre performed as intermediate on the state language proficiency assessment. Andre receives special education services for reading and writing. His teacher reports that he is reading at a first-grade level. Typically, Andre is pulled out for special education services for the majority of the language arts instruction (both during reading and writing periods). When in the classroom during reading and writing instruction, Andre did not sit with the rest of the students. He sat in the back of the classroom, frequently looking at comics. He was heard saying things like "I can't read" or "I can't write" when asked to contribute or attempt participation when he was in the general education classroom.

\section{The Comics Unit: Scope and Sequence}

The comics unit spanned four weeks and was designed through a collaboration between Lindsey (first author) and Sam (classroom teacher) (Reid \& Moses, 2020). The aim of the unit was to support students in moving from being readers of comics to becoming composers of comics. By the end of the unit, each student produced a six-page comic. As the comics genre was new to both the researcher and teacher, in the opening session, the teacher let the students know that, "This style of book is really new for me. I'm learning actually along with you. So is Lindsey." The researcher, teacher, and students learned alongside and from each other as they worked towards becoming comic book authors themselves.

During the first week of instruction, students immersed themselves in reading and enjoying self-selected comics texts. The researcher and teacher modeled reading comics texts and drew students' attention to comic book features (e.g. panels, gutters, narrative boxes, and speech bubbles). Students explored why authors and artists might choose to use those conventions. In week two, students started writing their own narrative plots and comic book drafts. Students wrote their story outlines on a graphic organizer and then used draft comic book pages with empty panels to construct their story in comic book format (student could create their own panels on a blank page or use one of the 8 templates that included 2-12 panels per page). During week three, students transitioned from the drafting phase to revising their work and beginning a final draft. Both the researcher and teacher assisted students with the editing. During week four, final drafts were completed and 
submitted to the publisher. Throughout the unit, students shared ideas about narrative construction and comic design during whole-group sessions. Student choice was embedded and privileged in this unit. Students self-selected the texts they read, decided which comic book features they used (there were no requirements of which design features or how many), and chose the tools they used to construct their comic. Students also had the authority to take-up or decline any editing and feedback suggestions offered by their teacher and peers.

The unit concluded with an author's celebration event. Three copies of each student's comic were professionally printed with saddle stich binding. One copy was for the student, a second copy was for the classroom library, and a third copy would be housed at the researcher's university. The teacher invited students' family members to attend. The student authors walked a red carpet, signed copies of their published work, and celebrated their comics with classmates and family.

\section{Data Collection}

We used camcorders and microphones to capture the literacy period. The recordings included whole-group and small-group instruction, partner interaction, independent reading and writing, teacher conferences, discussion groups, and researcherled conferring. We conducted interviews with students about their perspectives on literacy and their literate identity before and after the unit. We also utilized Voxer, a voicemessaging app, to replace written teacher reflections and maintain communication with Sam. We collected student artifacts such as planning documents, sketches, drafting, graphic organizers, revision documents, edited writing, and final drafts of their comic compositions. We photographed the changing environment, student-created artifacts, and students reading and writing together and independently.

\section{Data Analysis}

We completed the first layer of analysis weekly by transcribing the video recordings of the student interviews and classroom video. We used open coding (Strauss $\&$ Corbin, 1998) to document and discover meaning from video transcriptions. Initial open coding of identity work involved codes like expert, novice, student role, teacher expectations, confirming expertise, discrediting contribution, etc. These initial open codes lead us to begin examining roles of positionality and pattern coding (Miles \& Huberman, 1994), through which we grouped initial codes and identified recurring literacy practices that served as tools to enact literate identities.

For a more in-depth examination of identity negotiations, we selected representative transcripts and utilized an analytical lens grounded in Positive Discourse Analysis (PDA) (Martin, 2004) by integrating a "focus on community, taking into account how people get together and make room for themselves in the world in ways that redistribute power without necessarily struggling against it" (p. 183). We examined these literacy events specifically for ways in which the case studies were able to position themselves as experts and authors. We value Critical Discourse Analysis (CDA) for its ability to expose power and marginalization, but we also agree with Martin's (2004) suggestion that the lack of PDA hinders researchers' understanding of how positive change, such as students who have been historically marginalized repositioning themselves as classroom experts and authors, can happen across contexts. Our analysis consisted of three 
areas of focus based on our original rounds of coding: positionality, design features, and literacy practices. See Table 1 for an example.

\section{Author Positionality}

Lindsey is a Caucasian associate professor of literacy. She was formerly an elementary classroom teacher in a bilingual elementary school. She has a M.A. in ESL, Multicultural, Bilingual Education, and a doctorate in Reading and Culturally and Linguistically Diverse Education. She conducts classroom-based research focused on language, literacy, and identity development. Stephanie is a Caucasian assistant professor of literacy education, who previously taught English Language Arts in a suburban middle school in the midwestern United States. Her research focuses on multimodal literacy practices in K-8 classroom settings and examines how students represent and communicate their thinking using multiple modes and a broad range of semiotic resources that include (but are not limited to) Standard English.

We recognize that our backgrounds and educational experiences with which we identify have been privileged and were significantly different from the students in our study. We attempted to remain reflexive throughout the research process by keeping a research journal, checking and confirming interpretations of identity with the classroom teacher, and collecting multiple data sources for triangulation and conducting in-depth analysis to supporting our claims of negotiated identity. We acknowledge that our backgrounds influenced our research in additional ways that we have not realized.

\section{Findings}

In this section we show how Andre and Sabrina negotiated positive identities by using cultural tools and taking up literacy practices made available and/or validated through the multimodal writing curriculum. While both students asserted their expertise and constructed identities as successful comic book authors, they did so in different ways. While Andre negotiated a new identity as author and expert within his class, Sabrina sought to reconfirm and redefine the positive identity she had previously negotiated.

\section{Andre}

Andre's initial challenges with using traditional literacy practices made available in the classroom, such as extensive decoding and encoding in highly structured formats like five paragraph essays, positioned him as a non- or peripheral member of the literacy classroom community of practice. He rarely participated and did not sit with the group. However, there was a visible shift in his participation and identity negotiations when the new unit of multimodal writing began. He was able to use his knowledge of comics and design features to re-position himself not only as a member of the class, but as an expert. In this section we explore two instances of positive identity positioning. One instance involves Andre's public sharing of his expertise and knowledge that is beyond the scope of initial instruction. The second instance involves the introduction of a design feature not yet introduced by the teachers that gets taken up and appropriated repeatedly by the teacher and other students.

This first interaction took place during a lesson debrief with students after noticing they were having difficulty explaining the purpose for various comic conventions. Table 1 includes transcriptions and data analysis of positionality, evidence, design features, and 
literacy practices to help support claims of identity negotiations. The teacher makes direct connections to traditional prose-text literacy instruction "inner dialogue" and calls on a student who has performed well in previous traditional literacy practices to remind the class about this concept. However, Andre respectfully challenges both the teacher and student (using the accepted literacy practice of voluntary student input) by providing additional knowledge and referencing a design feature specific to comics that has not yet been introduced, thought bubbles. He distinguishes thought bubbles from speech bubbles, clarifying that the correct terminology is thought bubbles. Andre establishes himself as having expertise beyond that of the teacher. The teacher and researcher solidify his positioning by confirming and celebrating their new and expanded knowledge.

Table 1

Positive Discourse Analysis of Andre's Contribution to a Classroom Discussion

\begin{tabular}{|c|c|c|c|c|}
\hline TRANSCRIPT & Positionality & Evidence & $\begin{array}{l}\text { Design } \\
\text { Features }\end{array}$ & $\begin{array}{l}\text { Literacy } \\
\text { Practices }\end{array}$ \\
\hline $\begin{array}{l}\text { Teacher } \\
\text { Tell us, Elisabeth, } \\
\text { what is inner } \\
\text { dialogue, for a couple } \\
\text { of the kids that may } \\
\text { have forgotten. I } \\
\text { know we've talked } \\
\text { about it. }\end{array}$ & $\begin{array}{l}\text { Teacher } \\
\text { positions } \\
\text { Elisabeth as } \\
\text { expert - recall } \\
\text { definition. }\end{array}$ & $\begin{array}{l}\text { Asked to provide a } \\
\text { definition for class } \\
\text { ("us"; "we"). } \\
\text { Information recall } \\
\text { from previous class } \\
\text { discussion. }\end{array}$ & $\begin{array}{l}\text { Inner } \\
\text { dialogue } \\
\text { (traditional } \\
\text { prose-text } \\
\text { literacy } \\
\text { instruction) }\end{array}$ & $\begin{array}{l}\text { Teacher } \\
\text { request/student } \\
\text { response } \\
\text { during whole- } \\
\text { class } \\
\text { discussion. }\end{array}$ \\
\hline $\begin{array}{l}\text { Elisabeth } \\
\text { What it is is when } \\
\text { there's not a speech } \\
\text { bubble sometimes } \\
\text { around it, there can } \\
\text { be. It is when a } \\
\text { character's thinking } \\
\text { it. Not saying it out } \\
\text { loud. }\end{array}$ & $\begin{array}{l}\text { Elisabeth as } \\
\text { expert }\end{array}$ & $\begin{array}{l}\text { Explains her } \\
\text { understanding and } \\
\text { provides definition. }\end{array}$ & $\begin{array}{l}\text { Inner } \\
\text { dialogue } \\
\text { (traditional } \\
\text { prose-text } \\
\text { literacy } \\
\text { instruction) }\end{array}$ & $\begin{array}{l}\text { Student } \\
\text { response. } \\
\text { Providing } \\
\text { explanation to } \\
\text { class. }\end{array}$ \\
\hline $\begin{array}{l}\text { Teacher } \\
\text { Excellent. Right? } \\
\text { Don't we all have } \\
\text { those little } \\
\text { conversations in our } \\
\text { head all day long? } \\
\text { The little voice in } \\
\text { your head. Right? }\end{array}$ & $\begin{array}{l}\text { Teacher confirms } \\
\text { Elisabeth's } \\
\text { expertise. }\end{array}$ & $\begin{array}{l}\text { Use of rhetorical } \\
\text { questions - } \\
\text { especially "right?" } \\
\text { imply that the only } \\
\text { choice students } \\
\text { have is agreement. }\end{array}$ & $\begin{array}{l}\text { Inner } \\
\text { dialogue } \\
\text { (traditional } \\
\text { prose-text } \\
\text { literacy } \\
\text { instruction) }\end{array}$ & $\begin{array}{l}\text { Confirmation. } \\
\text { Teacher seeks } \\
\text { class } \\
\text { consensus }\end{array}$ \\
\hline
\end{tabular}




\begin{tabular}{|c|c|c|c|c|}
\hline $\begin{array}{l}\text { Andre } \\
\text { Mr. Sam, there's } \\
\text { another word for it } \\
\text { inner dialogue. } \\
\text { They're actually } \\
\text { called thought } \\
\text { bubbles. There's } \\
\text { speech bubbles, } \\
\text { thought bubbles, and } \\
\text { Elisabeth, it's cuz you } \\
\text { can call 'em inner } \\
\text { dialogue bubbles. The } \\
\text { right word for it is } \\
\text { thought bubbles. }\end{array}$ & $\begin{array}{l}\text { Expert - } \\
\text { correcting/adding } \\
\text { to teacher } \\
\text { knowledge }\end{array}$ & $\begin{array}{l}\text { Andre respectfully } \\
\text { challenges } \\
\text { Elisabeth's } \\
\text { expertise and Mr. } \\
\text { Sam's affirmation. } \\
\text { Confidence shown } \\
\text { in use of "actually" } \\
\text { and "the right word } \\
\text { for it." Andre } \\
\text { acknowledges } \\
\text { Elisabeth's } \\
\text { language but } \\
\text { knows he's } \\
\text { providing a } \\
\text { correction. }\end{array}$ & $\begin{array}{l}\text { Thought } \\
\text { bubble } \\
\text { (correct } \\
\text { comic book } \\
\text { terminology } \\
\text { referencing } \\
\text { visible } \\
\text { design) }\end{array}$ & $\begin{array}{l}\text { Voluntary } \\
\text { student input. } \\
\text { Extends } \\
\text { conversation } \\
\text { by correcting. }\end{array}$ \\
\hline $\begin{array}{l}\text { Lindsey } \\
\text { We might wanna put } \\
\text { a little sub-category } \\
\text { there. That was really } \\
\text { fancy high-level } \\
\text { knowledge that we } \\
\text { hadn't gotten into yet. } \\
\text { I think you're right. } \\
\text { Sometimes they draw } \\
\text { them differently. } \\
\text { Sometimes there's an } \\
\text { arrow } \\
\text { for the speech. } \\
\text { Sometimes for } \\
\text { thought bubbles, it's } \\
\text { curvy. }\end{array}$ & $\begin{array}{l}\text { Teacher affirms } \\
\text { Andre's } \\
\text { expertise - } \\
\text { builds on his } \\
\text { comment. }\end{array}$ & $\begin{array}{l}\text { Notes that this has } \\
\text { not yet been } \\
\text { discussed in school. } \\
\text { Andre's expertise } \\
\text { from beyond } \\
\text { school. Continues } \\
\text { Andre's thinking } \\
\text { by thinking through } \\
\text { the design of } \\
\text { thought bubbles. }\end{array}$ & $\begin{array}{l}\text { Thought } \\
\text { bubble } \\
\text { (correct } \\
\text { comic book } \\
\text { terminology } \\
\text { referencing } \\
\text { visible } \\
\text { design) }\end{array}$ & $\begin{array}{l}\text { Confirmation } \\
\text { and } \\
\text { celebration. } \\
\text { Teacher } \\
\text { extends } \\
\text { student's point } \\
\text { and adds } \\
\text { further } \\
\text { clarification. }\end{array}$ \\
\hline $\begin{array}{l}\text { like a cloud. } \\
\text { ing to the person. }\end{array}$ & $\begin{array}{l}\text { Andre positions } \\
\text { himself as expert } \\
\text {-agrees and } \\
\text { expands. }\end{array}$ & $\begin{array}{l}\text { Confirms the } \\
\text { teacher is correct. } \\
\text { Expands on and } \\
\text { explains clearly the } \\
\text { design feature. }\end{array}$ & $\begin{array}{l}\text { Thought } \\
\text { bubble } \\
\text { (correct } \\
\text { comic book } \\
\text { terminology } \\
\text { referencing } \\
\text { visible } \\
\text { design) }\end{array}$ & $\begin{array}{l}\text { Voluntary } \\
\text { student input: } \\
\text { Agreement } \\
\text { and further } \\
\text { extension. }\end{array}$ \\
\hline $\begin{array}{l}\text { Teacher } \\
\text { Interesting. I didn't } \\
\text { know that. You guys } \\
\text { are teaching me. }\end{array}$ & $\begin{array}{l}\text { Teacher } \\
\text { positions himself } \\
\text { as learner/novice } \\
\text { and Andre as } \\
\text { expert/ teacher. }\end{array}$ & $\begin{array}{l}\text { Teacher reverses } \\
\text { traditional } \\
\text { classroom role in } \\
\text { stating himself as } \\
\text { the learner. Andre } \\
\text { has stated ideas his }\end{array}$ & $\begin{array}{l}\text { Thought } \\
\text { bubble } \\
\text { (correct } \\
\text { comic book } \\
\text { terminology } \\
\text { referencing }\end{array}$ & $\begin{array}{l}\text { Teacher } \\
\text { mistake/gap in } \\
\text { knowledge. } \\
\text { Modeling } \\
\text { learning. }\end{array}$ \\
\hline
\end{tabular}




\begin{tabular}{|l|l|l|l|l|}
\hline & $\begin{array}{l}\text { teacher admits he } \\
\text { didn't know. }\end{array}$ & $\begin{array}{l}\text { visible } \\
\text { design })\end{array}$ & \\
\hline
\end{tabular}

Sam reported that he saw a positive shift in Andre. He said Andre rarely, if ever, participated in the classroom practice of voluntary student input during the previous units. During the multimodal unit, Andre's expertise was signaled on many instances through modeling, voluntary student input, agreement/confirmation of other's thinking, providing feedback to other students, and expanding on (or correcting) teacher and student thinking. As Andre continued to share new information, clarify student and teacher misconceptions, and introduce new design features during the second week, students began to acknowledge his expertise by seeking out feedback, asking him questions, and attempting to collaborate with him during writing time. Students also signaled his expertise by taking up ideas or design features he used and introduced in their own writing.

In the second interaction, Andre describes his use of multiple techniques and design features to communicate meaning in his comic composition during a whole-class debriefing session (see Figure 1 for the panels being discussed). The teacher initially points out Andre's work and identifies a new feature, a close-up image of a book lying on the path. Sam asks Andre to share his thinking and reasoning behind using the close-up with his peers. The following conversion ensued:

Andre: Why I do that is 'cuz when I drew the first picture, I ignored, 'cuz I could barely see the book, 'cuz I drew it. I need a close-up of it, so people can see it.

Teacher: Why was that important, do you think, to the reader, to see the close-up of the book?

Andre: $\quad$ So they can know what it looks like. It's like some of the other-like the ends of the [inaudible] are ripped out kind of, close to falling out.

Teacher: If I didn't do that zoom in, would you reader know?

Andre: $\quad$ No.

Teacher: Guys, listen to what Andre's saying. A lot of you, what I notice, are doing a lot of stick figures, but things are far away. You may wanna take that technique, and, if there's something important to your story line...there may be a point where you need to zoom in on that. Your reader needs to see the details. If everything's like I'm just looking at everything from a distance, if you hadn't done that, Andre, I wouldn't have known that the book was tattered, or what the title was, or anything, right?

In this class conversation, the teacher used Andre's work to introduce a new design feature and encourages students to use it in their own writing. He drew attention to Andre's expertise, uses Andre's work as a model to demonstrate the feature, and asks Andre to discuss his purpose in using it in his composition. This positioned Andre as an expert composer who not only uses design features, but also explains the purpose behind his composition choices.

While Andre uses the correct terminology, close-up, the teacher refers to this design feature as a "zoom in." At the end of the writing period, the teacher calls on another student, Elijah, to share how he took up and used the "zoom in" feature (introduced and modeled 
by Andre) to enhance his comic composition. Elijah shared his work and use of the newly introduced design feature, further confirming Andre's positioning as an expert and author. This convention introduced by Andre was taken up and used in many of the students' comics.

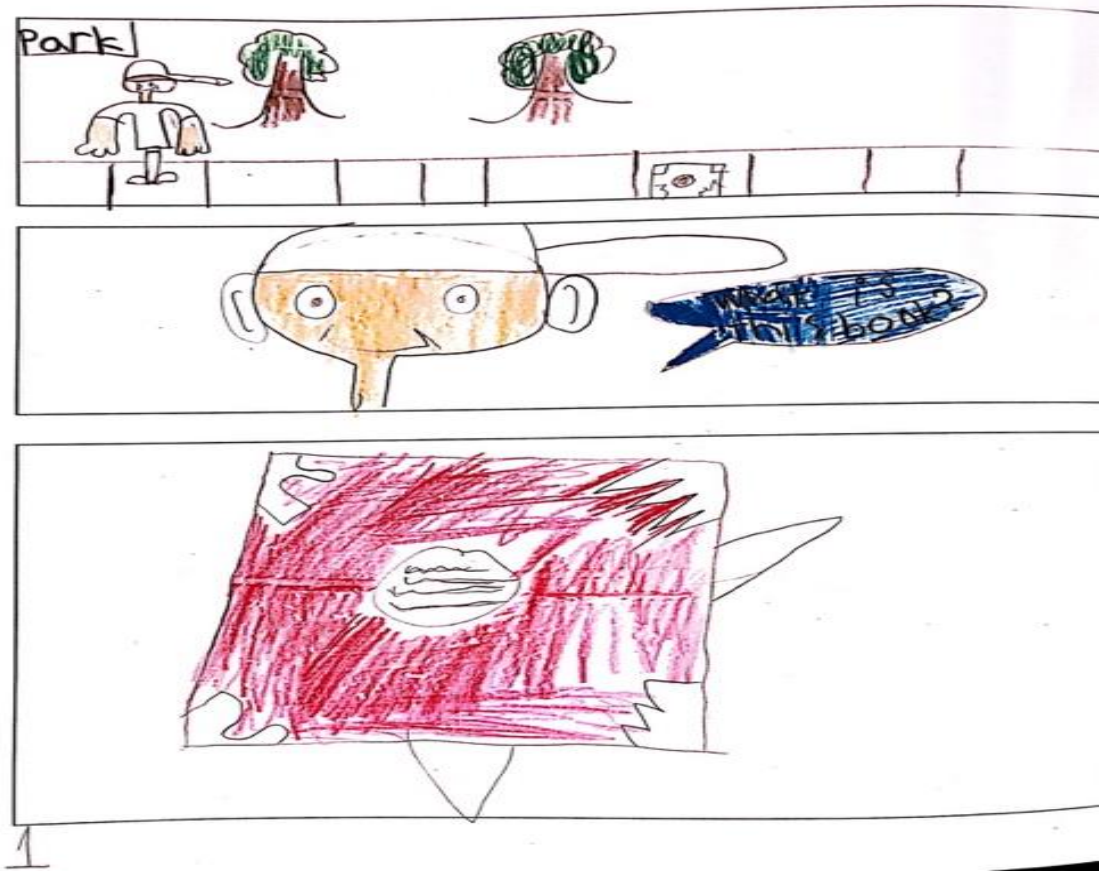

Figure 1. Andre's Comic Panels and Close Up

\section{Sabrina}

Sabrina's mastery of school literacy practices positioned her as an expert within this literacy classroom community. The teacher confirmed her expertise by calling upon her during whole-class briefings and publicly praising her creativity and ideas. Sabrina's classroom peers frequently sought her advice and input on their own work. Throughout the multimodal unit, Sabrina established additional ways to bolster her position as expert. Sabrina continued to utilize familiar tools and literacy practices, but she did so in combination with new design knowledge she gained during the unit. Additionally, when designing her comic, Sabrina also drew upon artistic knowledge she practiced at home. In this section, we explore two instances during which Sabrina confirmed her identity positioning. During the first instance, Sabrina assists a classmate with writing their comic book plot. The second instance shows Sabrina introducing a design feature that remained unique to her work: a speech bubble shared by multiple characters.

Table 2 includes transcriptions and data analysis of positionality, evidence, school literacy practices, and literacy practices. The interaction represented in Table 2 is the opening segment from a longer interaction between Sabrina and one of her class peers, Angelina. During this class period, students worked on a graphic organizer that supported them in constructing a plot for their comic book. Students could work independently or seek input from peers and adults in the classroom. Angelina asked Sabrina for advice regarding her story plot. In the following interaction, Sabrina confirmed her positionality 
as an expert in traditional literacy practices by demonstrating knowledge of story elements and narrative construction. Although Angelina, too, showed her understanding of the different story elements, it is Sabrina's ideas that drove the conversation and formed the foundation of Angelina's story arc. Initially, Angelina tried to insert her ideas, but at the end of this segment, her comments become questions for Sabrina. Angelina trusted Sabrina's opinions and valued Sabrina's contributions to her story.

Table 2

Positive Discourse Analysis of an Interaction Between Sabrina and Angelina

\begin{tabular}{|c|c|c|c|c|}
\hline TRANSCRIPT & Positionality & Evidence & $\begin{array}{l}\text { School } \\
\text { Literacy }\end{array}$ & $\begin{array}{l}\text { Literacy } \\
\text { Practices }\end{array}$ \\
\hline $\begin{array}{l}\text { Sabrina } \\
\text { Maybe the first part } \\
\text { could be like it's } \\
\text { Christmas Eve and the } \\
\text { kids are super excited } \\
\text { to wake up in the } \\
\text { morning. }\end{array}$ & $\begin{array}{l}\text { Sabrina positions } \\
\text { herself as expert - } \\
\text { providing feedback } \\
\text { and suggestions to } \\
\text { someone else }\end{array}$ & $\begin{array}{l}\text { Provides suggestions: } \\
\text { "maybe..." Sabrina } \\
\text { suggests ideas for the } \\
\text { story opening, } \\
\text { partaking in the } \\
\text { construction of } \\
\text { Angelina's story from } \\
\text { the beginning. }\end{array}$ & $\begin{array}{l}\text { Story arc / } \\
\text { Story } \\
\text { elements }\end{array}$ & $\begin{array}{l}\text { Peer } \\
\text { Collaboration: } \\
\text { one student } \\
\text { offers advice to } \\
\text { another }\end{array}$ \\
\hline $\begin{array}{l}\text { Angelina } \\
\text { Or the rising action } \\
\text { could be- }\end{array}$ & $\begin{array}{l}\text { Angelina positions } \\
\text { herself as expert - } \\
\text { uses correct } \\
\text { literary } \\
\text { terminology. } \\
\text { Positioned as } \\
\text { learner - Sabrina } \\
\text { doesn't let her } \\
\text { finish idea. }\end{array}$ & $\begin{array}{l}\text { Provides literary terms } \\
\text { ("rising action") but } \\
\text { does not / is not } \\
\text { permitted to complete } \\
\text { thought. }\end{array}$ & $\begin{array}{l}\text { Story arc / } \\
\text { Story } \\
\text { elements }\end{array}$ & $\begin{array}{l}\text { Peer } \\
\text { Collaboration: } \\
\text { Attempts to build } \\
\text { on prior idea }\end{array}$ \\
\hline $\begin{array}{l}\text { Sabrina } \\
\text { The rising action could } \\
\text { be to open up their one } \\
\text { toy and then on } \\
\text { Christmas morning- }\end{array}$ & $\begin{array}{l}\text { Positions herself as } \\
\text { expert - providing } \\
\text { feedback and } \\
\text { suggestions. }\end{array}$ & $\begin{array}{l}\text { Suggestions: "could } \\
\text { be". Expert } \\
\text { positioning solidified } \\
\text { by not letting Angelina } \\
\text { express idea; using } \\
\text { correct literary } \\
\text { terminology. Sabrina } \\
\text { continues the story she } \\
\text { started. }\end{array}$ & $\begin{array}{l}\text { Story arc / } \\
\text { Story } \\
\text { elements }\end{array}$ & $\begin{array}{l}\text { Peer } \\
\text { Collaboration: } \\
\text { one student } \\
\text { offers advice to } \\
\text { another }\end{array}$ \\
\hline $\begin{array}{l}\text { Angelina } \\
\text { Oh yeah. The climax } \\
\text { is - }\end{array}$ & $\begin{array}{l}\text { Angelina positions } \\
\text { herself as expert - } \\
\text { uses correct } \\
\text { literary } \\
\text { terminology. } \\
\text { Positioned as } \\
\text { learner - Sabrina }\end{array}$ & $\begin{array}{l}\text { Provides literary terms } \\
\text { ("climax") but does } \\
\text { not / not permitted to } \\
\text { complete thought. }\end{array}$ & $\begin{array}{l}\text { Story arc / } \\
\text { Story } \\
\text { elements }\end{array}$ & $\begin{array}{l}\text { Peer } \\
\text { Collaboration: } \\
\text { Attempts to } \\
\text { share idea }\end{array}$ \\
\hline
\end{tabular}




\begin{tabular}{|l|l|l|l|l|}
\hline & $\begin{array}{l}\text { doesn't let her } \\
\text { finish idea. }\end{array}$ & & & \\
\hline $\begin{array}{l}\text { Sabrina } \\
\text { Maybe the climax } \\
\text { would be like three } \\
\text { days later the kids start } \\
\text { seeing weird things. }\end{array}$ & $\begin{array}{l}\text { Positions herself as } \\
\text { expert - providing } \\
\text { feedback and }\end{array}$ & $\begin{array}{l}\text { Suggestions: “maybe" } \\
\text { "would be". Expert } \\
\text { positioning solidified } \\
\text { by not letting Angelina } \\
\text { express idea; using } \\
\text { correct literary } \\
\text { terminology. }\end{array}$ & $\begin{array}{l}\text { Story arc / } \\
\text { Story } \\
\text { elements }\end{array}$ & $\begin{array}{l}\text { Peer } \\
\text { Collaboration: } \\
\text { one student } \\
\text { offers advice to } \\
\text { another }\end{array}$ \\
\hline $\begin{array}{l}\text { Angelina } \\
\text { The doll moves? }\end{array}$ & $\begin{array}{l}\text { Angelina asks Sabrina } \\
\text { about Angelina's own } \\
\text { astory plot. Questions } \\
\text { shows increased } \\
\text { commitment to } \\
\text { Sabrina's story ideas. }\end{array}$ & $\begin{array}{l}\text { Story arc / } \\
\text { plot / Story } \\
\text { elements }\end{array}$ & $\begin{array}{l}\text { Peer } \\
\text { Collaboration: } \\
\text { one student asks } \\
\text { advice of } \\
\text { another }\end{array}$ \\
\hline
\end{tabular}

This interaction is characteristic of Sabrina's positive identity in this literacy classroom, an identity confirmed by her peers, her teacher, and by Sabrina herself. In the class debrief at the end of the lesson in which the above interaction took place, Sam called upon Sabrina to share something that went well, an idea that might help someone else, or something of which she was proud. Sabrina responded she was proud to have helped Angelina. She explained Angelina "needed a little bit more excitement" so she "gave her a little bit of academic feedback." She then explained helping Angelina made her feel "more confident" about her own story. Providing feedback to her classmates enabled Sabrina to maintain her position as expert within the classroom. The positive acceptance and uptake of her ideas by the other members of classroom supported her in her identity negotiation work. Sabrina used independent work-time, peer-collaboration opportunities, and the whole class debrief to her advantage.

In the second interaction, Sabrina guides Lindsey through her final comic book draft. During the conversation, Sabrina positioned herself as both a story teller and comic book designer. She focused on her narrative and the design features she used to tell her story. Sabrina guided Lindsey through the opening to her story. Sabrina's main character, Nicki, decides to run away from home because her family members do not appear to notice she is there. Here, Sabrina explains the art and design elements she used to represent what happens next.

Sabrina: Over here, there are the brother and the sister, and they're fighting. In her mind, she's saying that she's leaving because nobody notices she's even there. (Referring to Figure 2)

Lindsey: $\quad$ Mm-hmm.

Sabrina: Then we're taking to the outside point of view, and the city is right here. It's night time now because they've been fighting for so long. She's saying, "I guess it's time to go," because she knows it's time to leave. In the next panel, there's the city, once again, with all their bright lights on. She's, in 
her mind, it's into the city. As you can see, there's the movement. Because I knew she wasn't going to be looking at us while she's running to the city, I made her head, but it's actually the back of her head. You can see her ponytail. I made it a lot darker than this hair, because it's more puffed out than the rest of her hair. (Referring to Figure 2)

Lindsey: Great. I love that. I was going to ask you about that, but that makes a lot of sense. She's running into the city.

Sabrina: Yeah.

Lindsey: Okay. Talk to me about this page.

Sabrina: $\quad$ On this page, I split the panel because I knew there was going to be two pictures. It says it's three days later, because she ran into the city and she got lost for so many days.

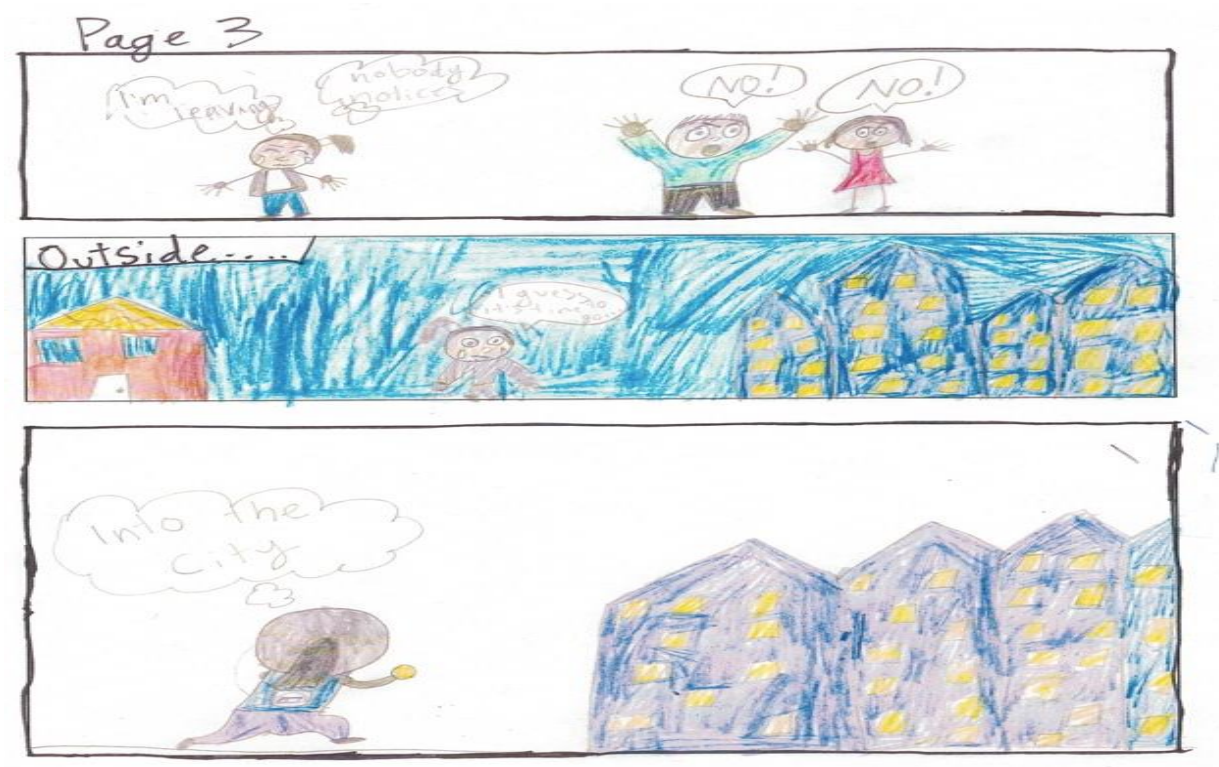

Figure 2. Sabrina's Comic (Perspective)

In this conversation, Sabrina positioned herself as an expert storyteller who can build a plot, create characters with motivations that impact their behavior and choices, and play with perspective, showing us both the inside of a character's mind as well as the external setting in which the character is situated. Plot, character motivation and behavior, and point of view belong to traditional school literacy practices involving the analysis and construction of fictional texts. However, these school literacy elements are broadcast to the reader through modes beyond language. Sabrina used speech bubbles to house the words the character was thinking, and she demonstrated design expertise in her use of comic book panels. She articulated the sequence of her panels and explained her decision to split a panel.

Sabrina also drew upon art knowledge and skills she had developed at home. She is able to depict movement and perspective through her drawings, as well as through her use of language and design elements. According to Sabrina, this unit made her parents happy because "they really got to see my creativity shine through because they always 
knew that I love to draw." Throughout this unit, Sabrina was aware of her audience. She enjoyed sharing her ideas with her peers, but she also constructed her text for the future reader of her work. Her greatest challenge in creating the comic book was, "trying to find something the readers would enjoy but also something that I would also like." As an expert storyteller, writer, and comic designer, Sabrina designs and creates with future publication and dissemination in mind.

\section{Discussion}

As both Low (2012) and Jiménez and Meyer (2016) observed, comics tend to fall outside of the traditional literary canon and are not often considered to be readerly or academic texts. However, the two students featured in this article produced complex multimodal narratives and used both words and images to impact their audience. Andre experimented with gutters and explored what meaning might be constructed within the space between panels. Sabrina played with internal and external perspectives, both visually and in the written components of her comic. Both students used images and design features strategically, as tools to enhance both the story they constructed and the message they wished their audience to receive. Both students also created complex texts and utilized the meaning potential of written language, images, and design features. Andre and Sabrina demonstrated that they could combine multiple modes of representation and communication in service of the story they were telling.

In addition, the multimodal unit widened the range of tools and resources that permitted participation in the classroom community (Wertsch, 1998). This research demonstrates a specific extended learning event that allowed the case study students to find affinity in the classroom and to establish their identities as experts in something, while engaging in a learning unit that considered literacy skill development. Bilingual students of color who attend low-income public schools have been historically marginalized by traditional literacy practices, restrictive language policies, and experiences of classism and racism. These experiences undoubtedly effect students' identity development ability to negotiate positive and successful participation in the literacy community. The affective aspect of belonging, along with the high interest topic of comics, assists the motivation to participate in the project for Andre. For Sabrina, her authority is reaffirmed through collaboration with peers, so the tool of the writing workshop allowed her continuity in her view of herself as expert. Within this literacy classroom community, the comics were valued and positioned as texts worthy of study, design, and production. Sam increased the variety of tools, modes, and meaning-making opportunities available to students. This expansion subverted the privilege assigned to assessment and essayist literacy orientations (Gee \& Hayes, 2011), orientations that support the kinds of literacy performances that are only relevant within institutions of formal schooling.

Through the multimodal writing unit, Andre and Sabrina made visible tools and practices that had previously been restricted to their home environments. For Andre, reading comics at home allowed him to bring outsider expertise into the classroom with knowledge exceeding that of the classroom teacher. Sabrina was able to integrate her love of art, a practice that was primarily experienced at home, into her comic work as a way to continue to confirm and elevate her status as an expert. We believe that expanding upon current notions of authenticity could help eradicate the inside/outside of school boundaries that so frequently demarcates when certain literacy practices and semiotic tools can be used 
in powerful and authoritative ways. For example, in her consideration of authenticity, Behizadeh (2019) included multimodal forms of publishing within the third factor in her framework for meeting the authenticity needs of students, writing for impact. We suggest that explicit reference to multimodality and the availability of a wide range of semiotic tools and resources in the classroom would also strengthen the second component, expression over convention. Expression of ideas and representation of thinking should not be limited to written language.

Dyson (2018) noted the importance of belonging and inclusion to sociocultural and participatory understandings of literacy as situated practice. This perspective means moving beyond viewing literacy as merely skill acquisition (Street, 1984) to viewing literacy as practices embedded in communities of people. From the start of the unit, Sabrina demonstrated the identity benefits of being viewed as a successful literacy student. Sabrina worked to negotiate her positive identity, especially within this unit which required her to take up new tools and resources in order to confirm her authority, but her positioning was also confirmed and defined by her teacher and classmates. As Andre progressed through the unit and demonstrated his knowledge, his peers increasingly took up his ideas. In addition, Sam and Lindsey both publicly acknowledged Andre's expertise at times surpassed their own, thus subverting traditional classroom power structures. Instead of leaving the classroom to work, Andre worked among his peers, helping and supporting them when he could. These new relationships confirmed he belonged to this community of practice and that he was included.

\section{Conclusion}

This study adds to the current body of literature related to comics and identity work in classroom settings. Much of the work in this area has taken place in secondary settings. There remains a need for more research related to the constraints and affordances of using multimodal texts in elementary settings. In this setting, students from a wide range of traditional literacy proficiencies were able to negotiate positive identities. This analysis of multimodal composing experiences revealed possibilities for positive identity negotiations in elementary literacy settings. Of particular importance is the ability for students like Andre, who have been historically marginalized from traditional literacy practices, to have opportunities to share and document their competencies in literacy and re-position themselves as experts and authors. 


\section{References}

$\mathrm{Au}, \mathrm{K}$. (1993). Literacy instruction in multicultural settings. Harcourt Brace.

$\mathrm{Au}, \mathrm{K}$. (1998). Constructivist approaches, phonics, and the literacy learning of students of diverse backgrounds. In T. Shanahan \& F. Rodriguez-Brown (Eds.), National reading conference yearbook forty-seven (pp. 1-21). National Reading Council.

Behizadeh, N. (2019). Aiming for authenticity: Successes and struggles of an attempt to increase authenticity in writing. Journal of Adolescent \& Adult Literacy, 62(4), 411-419.

Bezemer, J., \& Kress, G. (2016). Multimodality, learning and communication: A social semiotic frame. Routledge.

Bishop, R. S. (1990). Mirrors, windows, and sliding doors. Perspectives: Choosing and Using Books for the Classroom, 6(3), ix-xi.

Bloome, D., Carter, S. P., Christian, B. M., Otto, S., \& Shuart-Faris, N. (2005). Discourse analysis and the study of classroom language and literacy events: A microethnographic perspective. Lawrence Erlbaum Associates.

Brenna, B. (2013). How graphic novels support reading comprehension strategy development in children. Literacy, 47(2), 88-94.

Carter, J. B. (2007). Transforming English with graphic novels: Moving towards our “Optimus Prime.” English Journal, 97(2), 49-53.

Christian, B. M., \& Bloome, D. (2004). Learning to read is who you are. Reading Writing Quarterly, 20(4), 365-384.

Comber, B. (2013). Schools as meeting places: Critical and inclusive literacies in changing local environments. Language Arts, 90(5), 361-371.

Cowan, K., \& Kress, G. (2017). Documenting and transferring meaning in the multimodal world: Reconsidering transcription. In F. Serafini \& E. Gee (Eds.), Remixing multiliteracies: Theory and practice from New London to new times (pp. 50-62). Teachers College Press.

Cummins, J. (2017) Teaching minoritized students: Are additive approaches legitimate? Harvard Educational Review, 87(3), 404-425.

Davis, D. S., \& Willson, A. (2015). Practices and commitments of test-centric literacy instruction: Lessons from a testing transition. Reading Research Quarterly, 50(3), 357-379.

Delpit, L. (2012). "Multiplication is for White people”: Raising expectations for other people's children. New Press.

Dyson, A. H. (2006). On saying it right (write): "Fix-Its" in the foundations of learning to write. Research in the Teaching of English, 41(1), 8-42.

Dyson, A. H. (2018). A sense of belonging: Writing (righting) inclusion and equity in a child's transition to school. Research in the Teaching of English, 52(3), 236-261.

Fernsten, L. (2008). Writer identity and ESL learners. Journal of Adolescent and Adult Literacy, 52(1), 44-52.

Flewitt, R. (2008). Multimodal literacies. In J. Marsh \& E. Hallet (Eds.), Desirable literacies: Approaches to language and literacy in the early years (pp. 122-139). SAGE Publications Ltd.

Gee, J. P. (2001). Identity as an analytic lens for research in education. Review of Research in Education, 25(2000-2001), 99-125.

Gee, J. P., \& Hayes, E. R. (2011). Language and learning in the digital age. Routledge. 
Grice, K. M., Rebellino, R. L. R., \& Stamper, C. N. (2017). Connecting across borders by reading without walls: Using non-prose narratives to multiply multicultural class content. English Journal, 107(1), 48-53.

Guccione, L. M. (2011). Integrating literacy and inquiry for English learners. The Reading Teacher, 64(8), 567-577.

Hall, L. A. (2009). Struggling reader, struggling teacher: An examination of studentteacher transactions with reading instruction and text in social studies. Research in the Teaching of English, 43(3), 286-309.

Hall, L. A. (2012). The role of reading identities and reading abilities in students' discussions about texts and comprehension strategies. Journal of Literacy Research, 44(3), 239-272. https://doi.org/10.1177/1086296X12445370

Harris, J. (1997). A teaching subject: Composition since 1966. Prentice Hall.

Heath, S. B., \& Street, B. V. (2008). On ethnography: Approaches to language and literacy research. Teachers College Press.

Holland, D., \& Leander, K. (2004). Ethnographic studies of positioning and subjectivity: An introduction. Ethos, 32(2), 127-139.

Janks, H. (2010). Literacy and power. Routledge.

Jennings, K. A., Rule, A. C., \& Vander Zanden, S. M. (2014). Fifth graders' enjoyment, interest, and comprehension of graphic novels compared to heavily-illustrated and traditional novels. International Electronic Journal of Elementary Education, 6(2), 257-274.

Jewitt, C., Bezemer, J., \& O'Halloran, K. (2016). Introducing multimodality. Routledge.

Jimenez, L. M., \& Meyer, C. K. (2016). First impressions matter: Navigating graphic novels utilizing linguistic, visual, and spatial resources. Journal of Literacy Research, 48(4), 423-447.

Kamler, B. (2001). Relocating the personal: A critical writing pedagogy. State University of New York Press.

Kersten, S. (2018). "We are just as confused and lost as she is": The primacy of the graphic novel form in exploring conversations around deafness. Children's Literature in Education, 49(3), 282-301.

Kleinfeld, E. (2019). Reimagining multimodality through UDL: Inclusivity and accessibility. In S. Khadka \& J. C. Lee (Eds.), Bridging the multimodal gap: From theory to practice (pp. 30-43). The University Press of Colorado.

Kress, G. (2010). Multimodality: A social semiotic approach to contemporary communication. Routledge.

Kress, G., \& Van Leeuwen, T. (2001). Multimodal discourse: The modes and media of contemporary communication. Arnold Publishers.

Low, D. E. (2012). "Spaces invested with content": Crossing the "gaps" in comics with readers in schools. Children's Literature in Education, 43(4), 368-385.

Low, D. E. (2017). Students contesting "colormuteness" through critical inquiries into comics. English Journal, 106(4), 19-28.

Luke, A. (2014). Defining critical literacy. In J.Z. Pandya \& J. Avila (Eds.), Moving critical literacies forward: A new look at praxis across contexts (pp. 19-31). Routledge.

Lave, J., \& Wenger, E. (1991). Situated learning: Legitimate peripheral participation. Cambridge University Press. 
Maggio, J. (2007). Comics and cartoons: A democratic art-form. Political Science \& Politics, 40(2), 237-239.

Massey, D. (2005). For space. Sage.

Meyer, C. K., \& Jiménez, L. M. (2017). Using every word and image: Framing graphic novel instruction in the expanded four resources model. Journal of Adolescent \& Adult Literacy, 61(2), 153-161.

Norton, B. (2003). The motivating power of comic books: Insights from Archie comic readers. The Reading Teacher, 57(2), 140-147.

Norton, B., \& Toohey, K. (2002). Identity and language learning. In R. B. Kaplan (Ed.), TheOxford handbook of applied linguistics (pp. 115-123). Oxford University Press.

Martin, J. R. (2004). Positive discourse analysis: Solidarity and change. Revista Canaria de Estudios Ingleses, 49(1), 179-200.

Merriam, S. B. (1998). Qualitative research and case study applications in education. Jossey-Bass.

Miles, M. B., \& Huberman, A. M. (1994). Qualitative data analysis: An expanded sourcebook (2nd ed.). SAGE.

Moje, E. B., Giroux, C., \& Muehling, N. (2017). Navigating cultures and identities to learn literacies for life: Rethinking adolescent literacy teaching in a post-core world. In K. A. Hinchman \& D. A. Appleman (Eds.), Adolescent literacies: A handbook of practice-based research (pp. 3-20). Guilford Publications.

Moje, E. B., Luke, A., Davies, B., \& Street, B. (2009). Literacy and identity: Examining the metaphors in history and contemporary research. Reading Research Quarterly, 44(4), 415-437. https://doi.org/10.1598/RRQ.44.4.7

Moll, L. C., Diaz, S., Estrada, E., \& Lopes, L. (1992). Making contexts: The social construction of lessons in two languages. In S. Arvisu \& M. Saravia-Shore (Eds.), Cross-cultural literacy (pp. 339-366). Garland Press.

Moses, L. (2013). Viewing as a cultural tool in the construction of meaning with expository texts for young bilinguals. Journal of Language and Literacy Education, 9(2), 72-93.

Moses, L., \& Kelly, L.B. (2017). The development of positive literate identities among bilingual and monolingual first graders. Journal of Literacy Research, 49(3), 393423. doi: 10.1177/1086296X17713291

Mlynek, A. (2020, February 25). "Yes, graphic novels count as 'real' reading. Here's why." Today's Parent. https://www.todaysparent.com/kids/school-age/graphicnovels-real-reading/

Ranker, J. (2007). Using comic books as read-alouds: Insights on reading instruction from an English as a second language classroom. The Reading Teacher, 61(4), 296-305.

Reid, S., \& Moses, L. (2020). Composing with words and images in a fourth-grade comics writer's workshop. Reading Teacher, 73 (4), 461-472. https://doi.org/10.1002/trtr.1864

Reinking, D., \& Bradley, B. (2008). Formative and design experiments: Approaches to language and literacy research. Teachers College Press.

Rice, M. F., \& Dunn, M. (2020). Supporting children's writing in inclusive classrooms with arts-based strategies. Teaching Exceptional Children, 52(3), 147-156. 
Strauss, A., \& Corbin, J. M. (1998). Basics of qualitative research: Techniques and procedures for developing grounded theory (2nd ed.). SAGE.

Street, B. V. (1984). Literacy in theory and practice. Cambridge University Press.

Thomas, E. E., \& Stornaiuolo, A. (2016). Restorying the self: Bending toward textual justice. Harvard Educational Review, 86(3), 313-338.

Torres, F. L., \& Tayne, K. (2017). Super heroes, villains, and politics: Elementary youth superhero narratives in an afterschool program. English Teaching: Practice \& Critique, 16(3), 375-390.

Vasudevan, L., Schultz, K., \& Bateman, J. (2010). Rethinking composing in a digital age: Authoring literate identities through multimodal storytelling. Written Communication, 27(4), 442-468.

Vygotsky, L. (1978) Mind in Society. Harvard University Press.

Wallner, L. (2019). Gutter talk: Co-constructing narratives using comics in the classroom. Scandinavian Journal of Educational Research, 63(6), 819-838.

Wenger, E. (1998). Communities of practice: Learning, meaning, and identity. Cambridge University Press.

Wertsch, J. V. (1998). Mind as action. Oxford University Press.

\section{Author Biography}

Lindsey Moses is an associate professor of Literacy at Arizona State University in the Mary Lou Fulton Teachers College. She is the program coordinator for the M.A. in Literacy Education. Her research interests include using sociocultural approaches to researching early literacy, bilingual learners, identity, and instructional practices to support language and literacy in diverse contexts.

Stephanie F. Reid is an Assistant Professor of Literacy Education in the Phyllis J. Washington College of Education at the University of Montana. Prior to pursuing her doctoral degree at Arizona State University, Stephanie taught middle school students English Language Arts for 15 years in England and the United States. Stephanie's research focuses on multimodal literacies pedagogy in elementary and middle school contexts. 